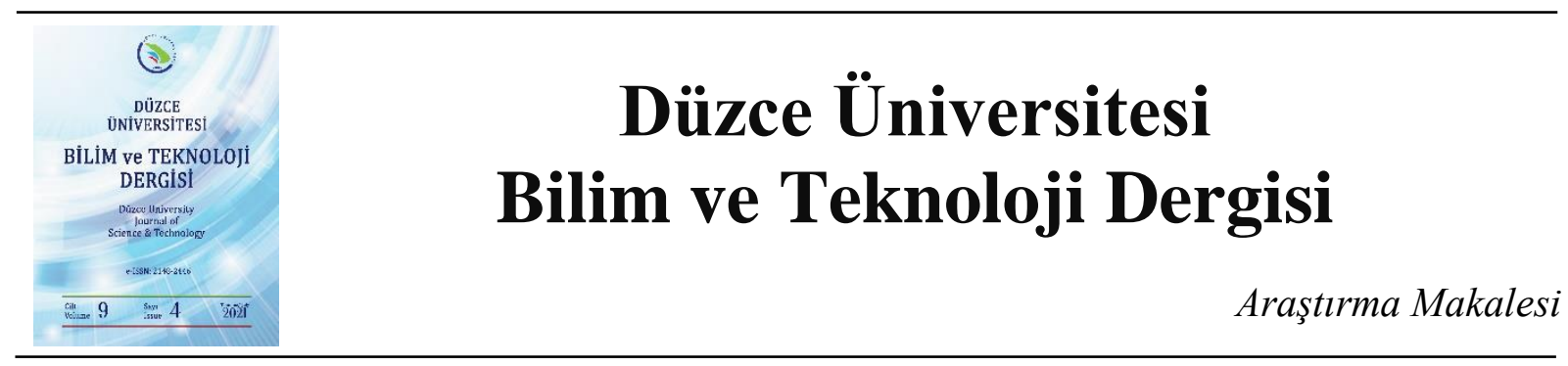

\title{
Su Parklarının Planlama ve Tasarım Kriterlerinin Saptanması ve Düzce Su Parkı Örneğinde Değerlendirilmesi
}

\author{
Özgür YERLİ ${ }^{\mathrm{a}}{ }^{\text {** }}$, (D) Esma AYKURT ${ }^{\mathrm{b}}$ \\ ${ }^{a}$ Peyzaj Mimarll̆ğ Bölümü, Orman Fakültesi, Düzce Üniversitesi, Düzce, TÜRKIYYE \\ ${ }^{b}$ Peyzaj Mimarlı̆̆ Bölümü, Fen Bilimler Enstitüsü, Ankara Üniversitesi, Ankara, TÜRKIYE \\ * Sorumlu yazarin e-posta adresi: ozguryerli@duzce.edu.tr
}

DOI: $10.29130 /$ dubited. 853448

\begin{abstract}
ÖZ
Su parkları, insan ihtiyaçları ve fonksiyonları düşünülerek, her yaş grubundan insanın bir arada eğlenerek zaman geçirdiği, çeşitli su aktivitelerini içeren eğlence mekanlarıdır. Yirminci yüzyılın ikinci yarısında ortaya çıkan su parkları, farklı yaş gruplarına hitap edebilen, suyun farklı özelliklerinin kullanıldığı çeşitli etkinliklerle boş zaman değerlendirme için cazip bir merkez haline gelmiştir. Bu araştırmada, su kavramı, su parklarında suyun önemi, su parkı kavramı ve genel özellikleri, standart bir su parkının nitel ve nicel açıdan incelenmesiyle optimum bir su parkı için olması gereken temel planlama ve tasarım kriterleri belirlenmiş ve bu kriterler baz alınarak bir gözlem formu oluşturulmuştur. Düzce Su Parkı örneği, gözlem formu kapsamında incelenmiş ve eksikleri tespit edilmiştir. Sonuç olarak Düzce Su Parkı'nda 7 adet kriterin optimum şartlara uygunluk sağladığı gözlenirken, 13 adet kriterin uygunluk sağlamadığı tespit edilmiştir. Uygunluk sağlamayan kriterler için önerilerde bulunulmuştur.
\end{abstract}

Anahtar Kelimeler: Su Parkı, tasarım, planlama, Düzce

\section{Determination of Planning and Design Criters of Water Parks and Evaluation in Düzce Water Park Example}

\begin{abstract}
Water parks are places of entertainment consisting of a variety of water activities, in which people of different ages enjoy spending time together, taking into account the needs and functions of humans. The water parks which came into being in the second half of the 20th century have become an attractive leisure center with various activities that can appeal to different age groups and use different characteristics of the water. Within this study, the water concept, the importance of water in water parks, the water park concept and its general characteristics, the basic planning and design criteria required for an optimal water park were determined by examining a standard water park in qualitative and quantitative terms and an observation form was created based on these criteria. The sample from the Düzce water park was reviewed as part of the observation form and gaps were identified. Consequently, it has been observed that 7 criteria met the optimal conditions in the Düzce Water Park, while 13 criteria did not. We have made suggestions for non-compliant criteria.
\end{abstract}

Keywords: Waterpark, design, planning, Düzce

Geliş: 04/01/2021, Düzeltme: 15/02/2021, Kabul: 19/02/2021 


\section{GİRIS}

Su barındırdığı özelliklerle eğlence parklarının bu amaçlarına ulaşmasında önemli bir araçtır. İlk eğlence parklarından itibaren günümüze dek su daima eğlence parklarında farklı biçimlerde yer bulmuştur. Su, doğa parklarında veya meydanlarda olduğu gibi, eğlence parklarında da yönlendirici ve odak noktasını belirleyici bir unsur olarak yer alır [1]. 20. yüzyıl başlarında bahçeler natüralistik özellik göstermekle birlikte, yapay kayalıklardan dökülen su oyunları önem kazanmıştır. Türk bahçelerinde su sürekli olarak yer alan bir tasarım elemanı olmuştur. Ancak hareketli su genellikle durgun suya tercih edilmiştir. Önceleri genellikle dört köşe olan havuzlar, sonraları yuvarlak formlu ve çok katlı olarak planlanmıştır [2].

Thales, suyu temel yaşam kaynağı olarak ele almıştır. Mısır'a seyahat ettiğinde Nil Nehri'nin taşmasının araziyi ne denli verimli hale getirdiğini görmüştür [3]. Bu sorularla günümüz su parklarının da temelleri atılmış oldu. George Millay SeaWorld yılları boyunca su parkı konsepti için eğlence birimleri toplamaya başladı. Su parkı için keşfettiği su odaklı elemanlar aslında farklı yerlerde, yalın halde kullanılmaktaydılar. George Millay 1977 yılında bu eğlence birimlerini bir araya getirerek resmi olarak kabul edilen ilk su parkı Wet'n Wild'ı Orlando'da kurmuş oldu [4].

Yapılan araştırma sonuçlarından elde edilen bilgilere göre Türkiye'de kurulmuş en eski su parkı 1992 yılında İstanbul Maltepe Sahil Yolu'nda yer alan Wonderland'dır. İşletmesi Sporting Eğlence Kompleksi ve Turizm Ltd. Şti.'ne ait olan tesis gerçek anlamda bir su parkı kavramını her ne kadar karşılamasa da bu yönde atılmış ilk adım olarak göze çarpmaktadır [5]. Ülkemizde de özellikle 1980'li yıllarda değişen ekonomik yapı eğlence sektörünü olumlu etkilemiş bunun sonucu olarak da Türkiye'de de farklı eğlence tipleri ve mekanları oluşmaya başlamıştır [6].

Su park1; içerdiği suya bağlı çok çeşitli aktivitelerle her yaştan insan grubuna hizmet eden, mekân nitelikleri ve program elemanları bakımından birbirlerinden çok değişik ölçeklerde tasarlanabilen suya dayalı aktif rekreasyonel alanlardır [7]. Geleneksel su parklarından türemişlerdir ancak daha gelişmiş olup kendi cazibeleri ile turistleri çekmektedirler [8].

Su parklarını ve su oyun sistemlerini oluşturan plancıların hayal güçlerini kullanmaları olaya çeşitlilik ve yenilik katarak, çeşitli modifikasyonlardaki su oyun sistemlerinin geliştirilmesini sağlar [9].

\section{A. SU PARKININ PLANLAMA ÖLÇEĞİ}

Su parklarının planlanmasında önemli olan unsurlar, yer seçimi, ihtiyaç-mekân ilişkisi ve ana tasarım kriterleridir. Su Parklarında planlama kriterleri, eğlence parklarının yer seçimi kriterlerinin belirlenmesi, projelendirilmesi ve uygulanması safhalarında veri sağlamak ve sağlanan verilerin analiz edilerek nihai karara ulaşılmasında hem bir altlık sağlamakta hem de projelendirme aşamalarının birçoğuna direk etki ederek projenin gelişimi için bir güç sağlamaktadır [10].

Su parkının planlama süreci program, mali ve fiziki planlamanın entegrasyonu, koordinasyonu ve organizasyonunu gerektirir. Bu tarz bir planlama doğası gereği döngüseldir ve mimari, strateji ve mastır planlama uzmanlarının faaliyetlerini doğru sıralamada gerçekleşmesini sağlamak için prosedürler ve çizelgeler geliştirilmesini gerektirir [11].

Yeni bir su parkı planlanırken detaylı bir fizibilite çalışması yapılması, su parkının yer seçimi ve tasarım kararları için son derece önemlidir. Fizibilite çalışması genellikle su parkı ve otel projelerinin performanslarını analiz etmek konusunda uzmanlaşmış, bağımsız danışman ekipler tarafından gerçekleştirilir [1]. Su parkları özellikle sıcak iklim kuşağında yer alan ülkelerde öne çıkan eğlence mekânlarından biridir. Bütün yıl kullanılabilir şekilde tasarlanabildiği gibi sadece yaz sezonunda kullanılabilecek şekilde de tasarlanabilir [12]. 
Eğlence parklarının ilk örnekleri, kullanıcıların park içinde rahat dolaşabilmeleri ve eğlence birimlerinin kolay kurulumu için mümkün olan en düz arazilerde konumlanmıştır. Günümüzde de çoğu eğlence park1 az engebeli alanlarda kurulmakta olsa da genişleme projelerinde park sınırlarının zorunlu bırakması veya düz arazinin yapım için maliyetli olması nedeniyle park ve eğlence birimi tasarımcıları "cadde seviyesi" üzerinde ya da altında ve daha zorlayıcı topoğrafyalarda eğlence birimleri tasarlamaya başlamıştır [13]. Ayrıca, topoğrafik yapı eğlence parklarının eğim ve bakı durumunu, dolayısıyla görsel değerlerini, alana ulaşılabilirlik ve giriş özelliklerini etkileyeceğinden planlama aşamasında önemlidir [6].

Su parkının getiri kapasitesinin ve finansal projeksiyonunun yapılabilmesi amacıyla çalışan giderleri, işletme maliyetleri gibi rutin giderler ve öngörülen net kazanç hesaplanır. Kazancın öngörülebilmesi için varsa mevcut su parklarıyla işletme geçmişleri karşılaştırılır. Ülkedeki ve dünyadaki sektör trendleri analiz edilir. Böylelikle belirli bir süreç için net proje getirisi hakkında fikir sahibi olunabilir [14].

\section{B. SU PARKININ TASARIM ÖLÇEĞI}

Küçük ölçekte planlanan, 30-60 dekarlık alanlar üzerinde tasarlanmış bir su parkında orta büyüklükte su kaydırakları, havuzlar, çocuk oyun havuzu, restoran, kafe, vb. gibi benzer ünitelerle geniş bir yeşil alan düzenlemesi söz konusudur. Bu su parklarında çeşitli su sporları yarışma gösterilerinin yapılması mümkündür [9]. Su parklarının daha büyük ölçekte planlanması multipark olarak isimlendirilen bir tasarım ortaya koyar. Multi-su parkları çok amaçlı oyun havuzları, bot havuzları, yüzme havuzları her türlü kaydırak sistemleri, nehir sistemleri ile yiyecek ne içecek ünitelerine sahip olarak planlanırlar. Daha büyük ölçekte planlanan multiparklar geniş bir yaş grubuna hizmet etmektedirler Çocuklar, annebabalar ve yaşlılar için birçok dinlenme ve eğlenme olanakları sağlar. 50-100 dekarlık alanlar üzerinde ve çeşitli topografik değişim ve formlar içeren yapıda tasarlanırlar [9].

İnsanların değişen eğlence anlayışlarına cevap verecek şekilde sürekli yenilenen su parkları, su, bitki ve insan arasında dengeli bir köprü kurularak oluşturulmaya çalışan mekanlarla tanımlanmaktadır. $\mathrm{Bu}$ dengenin kurulabilmesi ve fonksiyonel bir park oluşturulması açısından yapılan çalışma önemli bir bakış açısı oluşturmaktadır. Yıllar içerisinde su parklarındaki değişimi gereksinimleri ve planlama standartlarını belirlemede dünya çapında ve yerel ölçekte değerlendirmeler yapılmıştır. Su parklarının kullanıcıları açısından her yaş grubuna hitap etmesi tasarım materyallerinin de farklı1ıklar göstermesine neden olmaktadır. Belirli yaş grupları için hazırlanmış materyallerin bulunduğu parklar, suyun değişik formlarda, şekillerde, dokularda, seslerde ve renklerde planlanabilmesine olanak sağlamaktadır. Çalışmada, başarılı su parklarının ortaya konabilmesi amacıyla dünyada kabul görmüş, mevcut su parklarının nitel ve nicel açıdan incelenmesiyle başarılı bir su parkı için olması gereken temel planlama ve tasarım kriterlerinin belirlenmesidir. Su parkı alanları temel gözlem noktaları olmasına rağmen konunun daha geniş ve bilimsel olabilmesi açısından Düzce ilinde bulunan Düzce Su Parkı örnek alan olarak belirlenmiştir.

\section{MATERYAL VE YÖNTEM}

\section{A. MATERYAL}

Düzce İli 400,37 kuzey enlemleri ile 300,49 doğu boylamları arasında yer alır. 2593 km2 yüz ölçümüne sahip olan il Türkiye yüz ölçümünün $\left(783.577 \mathrm{~km}^{2}\right)$ binde 33 'ü kadar alan kaplamaktadır. Doğusunda Zonguldak ve Bolu batısında Sakarya illeri Kuzeyinde Karadeniz ile sınırdır. İl sınırları kuzey batıda Sakarya ve Melen Çayı Batı ve Güneyde Keremali, Elmalık, Güney Bolu, Sünnice dağlarının üst kısımları ile tabi sınırlar oluşturmaktadır. Denizden yüksekliği 160 m'dir [15]. Ulaşım ağına göre doğubat1 yönünde D-100 karayolu ile TEM otoyolu üzerinde bulunur. D-100 karayolu il merkezinden geçmektedir. Bu konumu ile İstanbul- Ankara arası geçiş şehri olarak nitelenebilir. İl merkezinin kuzeyinde Akçakoca, kuzey doğusunda Yığılca, kuzey batısında Çilimli ve Cumayeri, batısında Gümüşova, güney doğusunda Gölyaka ilçeleri yer alır [15]. 
Çalışmanın materyalini; yazılı ve görsel kaynaklar, gözlem formu ve çalışma alanı olan Düzce Su Parkı oluşturmaktadır. Gözlem formu, planlama ve tasarım kriterleri açısından optimum özelliklere sahip bir su parkının hangi özellikleri ne kadar içermesi gerektiğini anlatmaktadır. Bu form sayesinde herhangi bir su parkının planlama ve tasarım kriterleri açısından hangi özelliklere ne kadar sahip olduğu ölçülebilmektedir. Çalışmanın ana materyalini Düzce Merkez ilçe sınırları içerisindeki D-100 Karayolu üzerinde bulunan Düzce Su Parkı oluşturmaktadır. $15.000 \mathrm{~m}^{2}$ üzerine kurulu Düzce $\mathrm{Su}$ Parkında, $3.000 \mathrm{~m}^{2}$ otopark, $600 \mathrm{~m}^{2}$ açık yüzme havuzu, 180 ve $25 \mathrm{~m}^{2}$ iki adet kaydırak düşme havuzu, $300 \mathrm{~m}^{2}$ çocuk havuzu, $1.000 \mathrm{~m}^{2}$ kapalı fastfood ve düğün salonu bulunmaktadır [16].

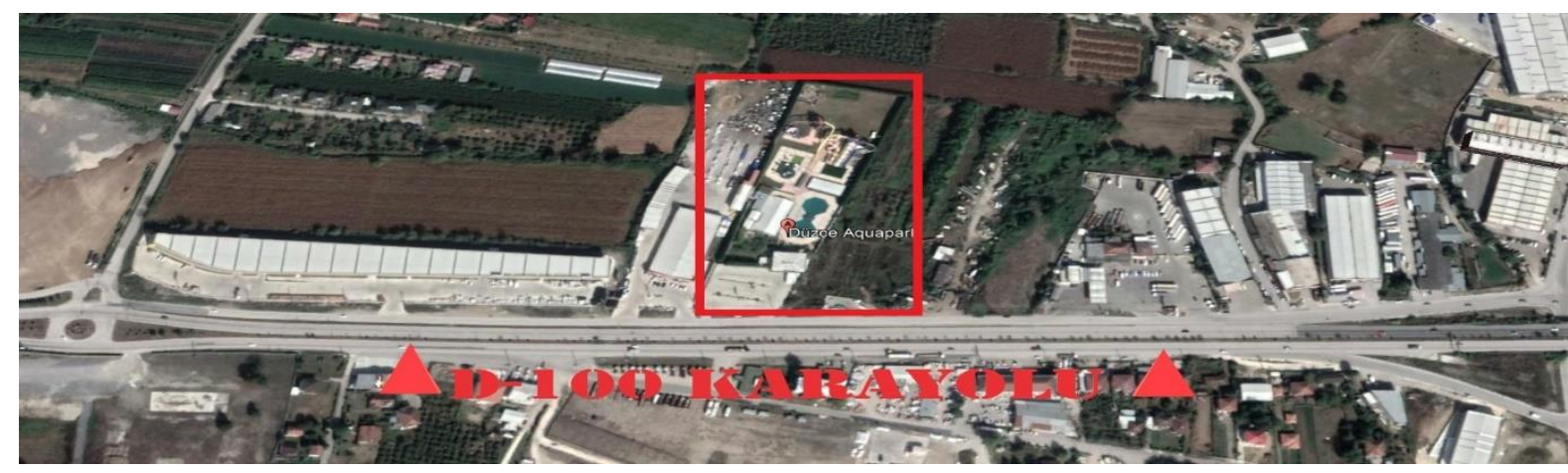

Şekil 1. Düzce Su Parkı [17].

Şekil 1.'de gösterilen Düzce Su Parkı'nda araştırmalar ve gözlemler yapılarak, bu alanların planlanması ve tasarımı gözlemlenmiştir. Tüm bu bilgiler doğrultusunda, su parklarının dinamik yapısının hangi şekilde işlediği, tasarım ve planlama anlamında neler yapılabileceği gibi konularda sonuçlar çıkarılmış olup su parkı tasarımında dikkat edilecek hususlar tespit edilip öneriler geliştirilmiştir.

\section{B. YÖNTEM}

Yapılan çalışmada izlenen yöntem; konu ile ilgili veri toplama, araştırma alanlarının incelenmesi, gözlem formunun oluşturulması ve bu forma göre yapılacak değerlendirme kriterleridir.

$\checkmark$ Araştırma alanı ile ilgili bilgiler hangi konularla ilgili çalışmalar yapılacağı, hangi kriterlerin araştırılacağı konusunda tespitler yapılmıştır. Düzce Su Parkı'nın işletmecisi ile yüz yüze görüşmeler yapılarak, park alanı ile ilgili fotoğraf, plan ve rapor bilgileri elde edilmiştir.

$\checkmark$ Gözlem için; arazi çalışmalarının yapılması, literatür araştırma sonuçları, daha önce yapılıış gözlem formlarının elde edilen veriler doğrultusunda seçilmiş olan Düzce Su Parkı Temmuz Ağustos 2020 tarihleri arasında gözlem formu yerinde tespitle doldurulmuş ve fotoğraflama çalışmaları ile alanın incelenmesi tamamlanmıştır.

$\checkmark$ Gözlem formu oluşturulurken Malkoç (2003) ve Akgül'ün (2006) su parkları üzerine yaptığı çalışmalar [7]- [5], Yaylacı'nın (2019) anaokulları üzerine yaptığı araştırma [18], Güneri' in (2019) meydanlar üzerine yaptığı çalışma [19], Tekinalp'in (2017) Japon bahçesi tasarım kriterleri üzerine yapmış olduğu çalışma [20], incelenmiş ve bu çalışmalarda belirlenen değerlendirme kriterleri sentezlenmiştir.

$\checkmark$ Çalışmanın bu bölümünde uygulama yapılacak su parkının konumu ve özellikleri açısından önemli olacak kriterleri göz önüne alınarak 20 kriter seçilmiştir. Seçilen kriterler tablolar halinde, değerlendirme kriterini ifade eden özellikler ve puanlama sistemi şeklinde açıklanmıştır.

$\checkmark$ Gözlem Formunun Değerlendirilmesi: Su parkının dinamik yapısının hangi şekilde işlediği, tasarım ve planlama anlamında neler yapılabileceği gibi konularda sonuçlar çıkarılmış olup başarılı bir su parkı için olması gereken kriterler gözlem formu oluşturularak belirtilmiştir. Yöntem bu gözlem formunda bulunan değerlendirme kriterlerine dayanmaktadır. Tablo 1.'de 
oluşturulan dereceli puanlama anahtarlarında, 3 puan (iyi) için gereken kriterler açılanmış, belirtilen kriterlere uygunluk açısından 2 puan (orta) ve 1 puan (zayıf) olarak belirlenmiştir.

Tablo 1. Değerlendirme Kriterleri.

\begin{tabular}{|c|c|c|c|}
\hline & $\begin{array}{l}\text { Değerlendirme } \\
\text { Kriteri }\end{array}$ & Değerlendirmede Kullanılan Özellikler & Puanlama \\
\hline \multirow{3}{*}{1} & \multirow{3}{*}{ Ulaşım-Konum } & $\begin{array}{l}\text { Su parkı girişinden en fazla } 350 \mathrm{~m} \text { mesafede (yaklaşık } 5 \text { dk' lık } \\
\text { yürüme mesafesi) toplu taşıma durağı bulunmaktadır. }\end{array}$ & 3 \\
\hline & & 350-1000 m mesafede toplu taşıma durağı bulunmaktadır. & 2 \\
\hline & & Yalnızca özel araçla gidilebilmektedir & 1 \\
\hline \multirow{3}{*}{2} & \multirow{3}{*}{ Şehir Nüfusu } & $\begin{array}{l}\text { (Günlük ziyaretçi kapasitesi) x (açık olduğu gün sayısı)>nüfusun } \\
\text { yarısı }\end{array}$ & 3 \\
\hline & & $\begin{array}{l}\text { (Günlük ziyaretçi kapasitesi) x (açık olduğu gün sayısı)>nüfusun } \\
\text { dörtte biri }\end{array}$ & 2 \\
\hline & & $\begin{array}{l}\text { Nüfusun dörtte biri> (Günlük ziyaretçi kapasitesi) x (açık olduğu } \\
\text { gün sayısı)> }\end{array}$ & 1 \\
\hline \multirow{3}{*}{3} & \multirow{3}{*}{ İklim } & Su parkının 4 ay ve daha fazla açık olması & 3 \\
\hline & & Su parkının 2-4 ay arası açık olması & 2 \\
\hline & & Su parkının 2 ay ve daha az açık olması & 1 \\
\hline \multirow{3}{*}{4} & \multirow{3}{*}{ Konaklama } & Su parkı bünyesinde otel düzeyinde konaklama & 3 \\
\hline & & Su parkı bünyesinde pansiyon düzeyinde konaklama & 2 \\
\hline & & Konaklama imkânı yoksa & 1 \\
\hline \multirow{3}{*}{5} & \multirow{3}{*}{$\begin{array}{c}\text { Otopark } \\
\text { Yeterliliği }\end{array}$} & Günlük kullanıcı sayısının dörtte birinden fazla ise & 3 \\
\hline & & Günlük kullanıcı sayısının dörtte biri ile sekiz de biri arasında ise & 2 \\
\hline & & Günlük kullanıcı sayısının sekizde birinden az ise & 1 \\
\hline \multirow{3}{*}{6} & \multirow{3}{*}{ Güvenlik } & Her $1.000 \mathrm{~m}^{2}$ alan için 10 ve üzeri güvenlik varsa & 3 \\
\hline & & Her $1.000 \mathrm{~m}^{2}$ alan için 5-10 arası güvenlik varsa & 2 \\
\hline & & Her $1.000 \mathrm{~m}^{2}$ alan için 5 altında güvenlik varsa & 1 \\
\hline \multirow{3}{*}{7} & \multirow{3}{*}{ Sağlık Birimi } & Su parkı bünyesinde revir ve sağlık personeli varsa & 3 \\
\hline & & Su parkı bünyesinde sağlık personeli ve ecza dolabı varsa & 2 \\
\hline & & Su park1 bünyesinde sadece ecza dolabı varsa & 1 \\
\hline \multirow{3}{*}{8} & \multirow{3}{*}{$\begin{array}{l}\text { Yeme - İçe } \\
\text { Birimleri }\end{array}$} & Restoran, kafe, fastfood, vitamin bar vs. varsa & 3 \\
\hline & & Restoran ve kafe varsa & 2 \\
\hline & & Sadece kafe varsa & 1 \\
\hline \multirow{3}{*}{9} & \multirow{3}{*}{$\begin{array}{l}\text { Soyunma } \\
\text { Birimleri - Duş - } \\
\text { Wc }\end{array}$} & $\begin{array}{l}\text { Günlük kullanıcı sayısının onda biri kadar Wc, duş, soyunma } \\
\text { dolapları varsa (günlük kullanıcı sayısı: n kişi - Wc-duş-soyunma } \\
\text { dolapları:x } \\
\text { n/10 } \leq \mathrm{x} \text { ) }\end{array}$ & 3 \\
\hline & & $\begin{array}{l}\text { Günlük kullanıcı sayısının onda biri ile yirmide biri arasında Wc, } \\
\text { duş, soyunma dolapları varsa (günlük kullanıcı sayısı: n kişi- Wc- } \\
\text { dus-soyunma dolapları:x } \\
\mathrm{n} / 10<\mathrm{x} \leq \mathrm{n} / 20 \text { ) }\end{array}$ & 2 \\
\hline & & $\begin{array}{l}\text { Günlük kullanıcı sayısının yirmide birinden az Wc, duş, soyunma } \\
\text { dolapları varsa (günlük kullanıcı sayısı: n kişi- Wc -dus -soyunma } \\
\text { dolapları:x }\end{array}$ & 1 \\
\hline
\end{tabular}


$\mathrm{x}<\mathrm{n} / 20)$

10

Kente uzaklık Kente uzaklığı $20 \mathrm{~km}$ ve daha yakınsa 3

Kente uzaklığı 21-50 km arası uzaklıkta ise $\quad 2$

Kente uzaklığ $51 \mathrm{~km}$ ve üzeri ise

Tablo 1 (devam). Dĕgerlendirme Kriterleri.

\begin{tabular}{|c|c|c|c|}
\hline \multirow{3}{*}{11} & \multirow{3}{*}{$\begin{array}{l}\text { Engelliler İçin } \\
\text { Düzenlemeler }\end{array}$} & Engelliler tüm kullanımlara rahatça ulaşıp kullanabiliyorsa & \multirow{2}{*}{$\begin{array}{l}3 \\
2\end{array}$} \\
\hline & & $\begin{array}{l}\text { Alanda gezinebiliyor ancak su ile ilgili kullanımlara kısmen } \\
\text { ulaşabiliyorsa }\end{array}$ & \\
\hline & & Sadece alanda gezinebiliyor kullanımlardan faydalanamıyorsa & 1 \\
\hline \multirow{3}{*}{12} & \multirow{3}{*}{ Bitkilendirme } & Ağaç ve ağaççıklar bulunuyorsa & 3 \\
\hline & & Çalı ve çalı grupları bulunuyorsa & 2 \\
\hline & & Yer örtücü ve çim alan barındırıyorsa & 1 \\
\hline \multirow{3}{*}{13} & \multirow{3}{*}{$\begin{array}{l}\text { Yerleşim Alanı } \\
\text { m}^{2}\end{array}$} & $15.000 \mathrm{~m}^{2}$ ve üzeri yerleşim alana sahipse & 3 \\
\hline & & $15.000-5.000 \mathrm{~m}^{2}$ yerleşim alanına sahipse & 2 \\
\hline & & $5.000 \mathrm{~m}^{2}$ den az yerleşim alanına sahipse & 1 \\
\hline \multirow{3}{*}{14} & \multirow{3}{*}{$\begin{array}{c}\text { Çocuk } \\
\text { Animasyon } \\
\text { Çeşitleri }\end{array}$} & 10 ve üzeri animasyon ve aquatowers varsa & 3 \\
\hline & & $5-10$ arasinda animasyon varsa & 2 \\
\hline & & 1-5 arasında animasyon varsa & 1 \\
\hline \multirow{3}{*}{15} & \multirow{3}{*}{$\begin{array}{l}\text { Kaydırak } \\
\text { Seçimi }\end{array}$} & 10 ve üzeri kaydırak varsa & 3 \\
\hline & & 5 ile 10 arasında kaydırak varsa & 2 \\
\hline & & 1 ile 5 arasında kaydırak varsa & 1 \\
\hline \multirow{3}{*}{16} & \multirow{3}{*}{$\begin{array}{c}\text { Su Öğesi } \\
\text { Kullanımı }\end{array}$} & 8 ve üzeri havuz- birden fazla nehir varsa & 3 \\
\hline & & 4 ile 8 arası havuz varsa & 2 \\
\hline & & 1 ile 3 arası havuz varsa & 1 \\
\hline \multirow{3}{*}{17} & \multirow{3}{*}{$\begin{array}{l}\text { Sezon Dışı } \\
\text { Kullanımı }\end{array}$} & Birden fazla etkinlik için kullanılıyorsa & 3 \\
\hline & & Sadece bir tür etkinlik için kullanılıyorsa & 2 \\
\hline & & Sezon dışı hiçbir kullanım yok & 1 \\
\hline \multirow{3}{*}{18} & \multirow{3}{*}{$\begin{array}{l}\text { Bilgi-İletişim } \\
\text { Levhaları }\end{array}$} & Park genelinde bilgi iletişim levhaları mevcutsa & 3 \\
\hline & & Sadece kaydırak ve havuzlarda mevcutsa & 2 \\
\hline & & İletişim levhaları yoksa & 1 \\
\hline \multirow{3}{*}{19} & \multirow{3}{*}{$\begin{array}{l}\text { Donatı } \\
\text { Elemanları }\end{array}$} & $\begin{array}{l}\text { Her } 100 \mathrm{~m}^{2} \text { içinde bir adet çöp, aydınlatma, şezlong ve oturma } \\
\text { elemanı varsa }\end{array}$ & 3 \\
\hline & & Her $100 \mathrm{~m}^{2}$ içinde sadece iki tür varsa & 2 \\
\hline & & Her $100 \mathrm{~m}^{2}$ içinde sadece bir tür donatı elemanı varsa & 1 \\
\hline \multirow{3}{*}{20} & \multirow[t]{3}{*}{ Hedef Kitle } & Bölgenin turist kitlesi, bulunduğu şehir, çevre il ve ilçeler & 3 \\
\hline & & Bulunduğu şehir, çevre il ve ilçeler & 2 \\
\hline & & Bulunduğu şehir & 1 \\
\hline
\end{tabular}

Tablo 1.'de verilen temsil derecesi değerlendirme tablosu oluşturulmuştur. Araştırma kapsamında incelenen, Türkiye'de bulunan Düzce Su Parkı örneğinin su parkı özelliklerini ne ölçüde temsil ettiğini tespit edebilmek için oluşturulan çizelge kullanılarak puanlama ve değerlendirme yapılmıştır. Değerlendirme kriterlerinin belirlenmesinin ardından sonuca ulaşabilmek için temsil grubunun ve temsil derecelerinin oluşturması gerekmektedir. Her kriterin kendi içinde sağladığı yeterlilikler baz alınarak 
elde edilen en yüksek puan 3 en düşük puan 1'dir. Tüm kriterleri sağlayan bir su park1 en yüksek 60 puan alırken, hiçbir yeterlilik gösteremeyen su parkı 20 puan almaktadır.

Tablo 2. Su Parkı Özelliklerini Temsil Derecesi Tablosu.

\begin{tabular}{lccc}
\hline Temsil Derecesi & 1(Zayif) & 2(Orta) & 3(İyi) \\
\hline Toplam Puan & $20-33$ & $34-46$ & $47-60$ \\
\hline
\end{tabular}

Değerlendirme sonucu elde edilebilen minimum ve maksimum puanlar doğrultusunda Tablo 2.'de verilen temsil derecesi değerlendirme tablosu gösterilmiştir.

\section{BULGULAR VE TARTISMA}

Düzce Su Parkı yaklaşık $15.000 \mathrm{~m}^{2}$ bir alanda 2009 yılında kurulmuştur. Park 30 kişilik personeli ile 1.100 kişi kapasite ile çalışmaktadır. Fakat özel durumlarda yapılacak düzenlemelerle 1.400 kişi kapasiteye ve personel sayısını 35 kişi ye ulaştı̆̆ tespit edilmiştir [21]. Düzce Su Parkı hakkında genel bilgiler Tablo 3.'de verilmiştir.

Tablo 3. Düzce Su Parkı Genel Bilgi Formu.

\section{Düzce Su Parkı}

\begin{tabular}{ll}
\hline Adres & D-100 Karayolu Üzeri Çerkez Taşköprü Mevkii Düzce Su Parkı \\
\hline Telefon Numarası & 05073137007 \\
\hline Web Adresi & www.duzceaquapark.com \\
\hline Mevkii & Çerkez Taşköprü Mevkii \\
\hline Tasarımcısı & Caner Hatipoğlu \\
\hline Kuruluş Tarihi & 2009 \\
\hline Kullanım Sezonu & 3 ay \\
\hline İşletmecisi & Caner Hatipoğlu \\
\hline Konumu & D-100 Karayolu Üzeri-Düzce merkeze 14,3 km uzaklıkta \\
\hline Kullanıcı Kapasitesi & 1.100 kişi (Özel Durumlarda 1.500 Kişi İçin Düzenleme Yapılmakta) \\
\hline Personel Sayısı & 30 \\
\hline Yerleşim Alanı & 15.000 m² \\
\hline Yüzey Şekilleri & Düz Alana Kurulmuştur. Planlamada Eğimden Yararlanma Yok \\
\hline Sezon Dışı Kullanım & Var \\
\hline Alana Ulaşım & Mevcut \\
\hline Peyzaj Mimarı & Esma AYKURT \\
\hline Kaydırak Firması & Polin Su Parkları ve Havuz Sistemleri Anonim Şirketi \\
\hline Uygulama Yapan Firma & Ulusal Yüzme Havuzları Su Kaydırakları San.ve Tic. Ltd. Şti. \\
\hline & \\
\hline
\end{tabular}

Düzce Su Parkı değerlendirme kriterlerinden aldığı puanlamalar;

1-Ulaşım-Konum: Düzce Su Parkı merkez yerleşime 13,5 km uzaklıkta olup, İstanbul - Ankara D-100 yolu üzerinde olduğu için konum bakımından iyi bir noktadadır. Şehir içi toplu taşıma, otobüs hatları 
ile birçok semtten direk veya aktarmalı olarak su parkına ulaşım sağlamak mümkündür. Ulaşım-konum kriterinden 3 puan almıştır.

2-Şehir Nüfusu: Düzce nüfusu 2019 y1lına göre 392.166'dir. Bu nüfus, 196.494 erkek ve 195.672 kadından oluşmaktadır [48]. Su parkının ziyaretçi sayısının bulunduğu ilin nüfusuna oranı su parkının çekim gücü hakkında fikir vermektedir. Belirlenen kriter için 2 puan almaktadır. (Günlük ziyaretçi kapasitesi) x (açık olduğu gün sayısı)>nüfusun dörtte biri).

3-İklim: Düzce'de Karadeniz Bölgesi’nin kıyı kesimlerinde görülen nemli ve fazla sert olmayan iklim hâkimdir. En çok yağış sonbahar ve kış aylarında görülmektedir. Yaz aylarında iki ay kadar kuraklık hissedilmektedir [22]. Düzce Su Parkı, hava sıcaklığına bağlı olarak Haziran - Eylül ayları arasında 3 aylık bir sezonda hizmet vermektedir [21]. Belirlenen kriter için 2 puan almaktadır.

4-Konaklama: Su parkının kendine özgü konaklama birimleri bulunmamaktadır. Bu yüzden şehir dışından gelen su parkı müşterileri için olumsuz etkilemektedir. Düzce Su Parkı, belirtilen değerlendirme kriterinden 1 puan almıştır.

5- Otopark: Park alanı girişinde, $3.000 \mathrm{~m}^{2}$ açık otoparkı mevcut olmakla birlikte otopark alanı yeterli şekilde bitkilendirilmemiştir. Şekil 2.' de gösterilmiştir. Alanda park eden araçlar güneşe maruz kalmaktadır. Otopark döşemesi beton kaplamadır. Yıllar içerisinde alan ile ilgili yenileme çalışmalarının yapılması alan kapasitesini arttırmıştır. Bu nedenle planlama esnasında planlanan otopark büyüklüğü yıllar içerisinde yetersiz kalmıştır. Bu sebepten yapılan değerlendirme kriterinden 2 puan almıştır (Günlük kullanıcı sayısının dörtte biri ile sekiz de biri arasında ise).

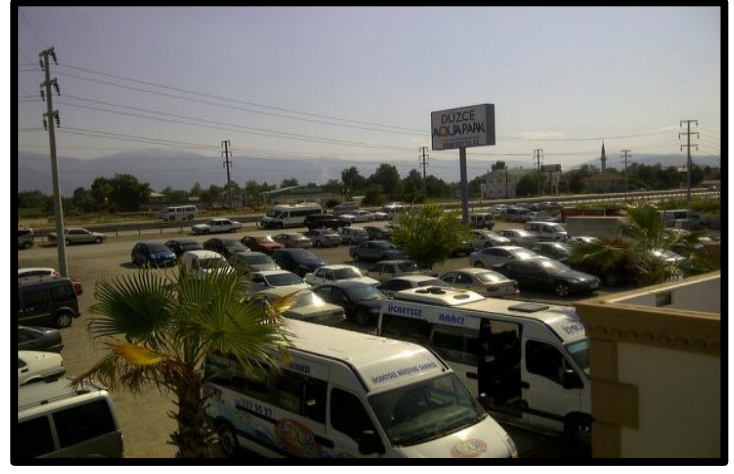

a)

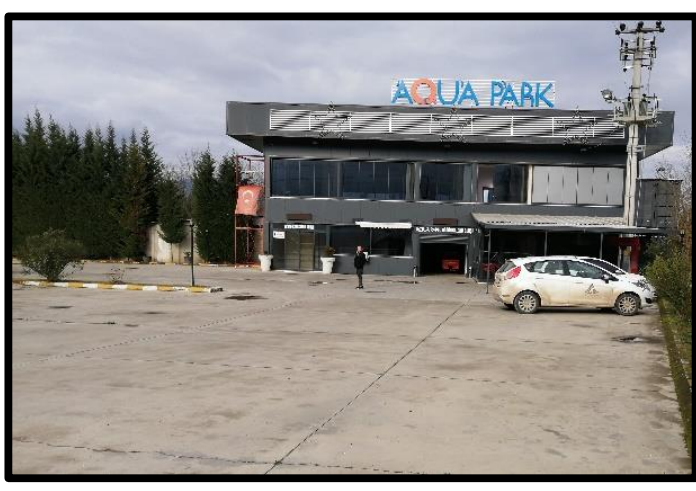

b)

Şekil 2. Düzce Su Parkı Otoparkı (a-b) [23].

6- Güvenlik: Güvenlik açısından değerlendirildiğinde, güvenlik görevlisi konusunda eksiklikler bulunmamaktadır. İki kaydırak için 1 güvenlik sorumlusu ve havuzlar için de 2 can kurtaran toplamda 8 güvelik görevlisi bulunmaktadır. Ama Güvenlik kriterinden 2 puan almıştır.

7-Sağlık Birimi: Alan içerisinde sağlık biriminin yer almadığı saptanmıştır. Sadece ecza dolabı bulunmaktadır. Bu sebepten değerlendirme kriterinden 1 puan almıştır.

8-Yeme-İçme Birimleri: Alanda $1.000 \mathrm{~m}^{2}$ olan fastfood ve kapalı düğün alanı aynı konumlanmıştır. Alan gündüz kullanımları restoran-kafe olarak, akşam ise düğün alanı olarak kullanılmaktadır. Tesis de restoran ve kafe bulunduğu için değerlendirme kriterinden 2 puan almıştır. 
9- Soyunma- Duş- Wc: Park alanında tek giriş olup kadın ve erkek olarak ayrılmıştır. Duş açık alanda 2 adet kapalı alanda ise kadın ve erkek olarak 2'şer adet, Wc soyunma odalarında 2'şer adet mescitte de 2 'şer adet, soyunma odaları 4'er adet olup kadın soyunma dolab1 150 adet, erkek soyunma dolabı ise 270 adet olarak gözlemlenmiştir. Günlük 1.100 kişi kapasiteli su parkı için yeterli sayıda duş, Wc ve soyunma dolabı olmadığı görülmüştür. Bu sebepten değerlendirme kriterinden 2 puan almıştır.

10- Kente Uzaklık: Düzce Su Parkı şehir merkezine 13,5 km uzaklıktadır. Bu sebepten değerlendirme kriterinden 3 puan almıştır.

11-Engelliler İçin Düzenlemeler: Alan düz bir zemin üzerine kurulması nedeniyle merdivenlere pek rastlanmamakta olup engelliler için havuzların kullanımı rahat olup kaydıraklara çıkma konusunda engellileri düşünerek yapılan herhangi bir düzenleme görülmemiştir. Düzce Su Parkı değerlendirme kriterinden 1 puan almıştır.

12-Bitkilendirme: Alan içerinde bitki örtüsü bulunmaktadır.

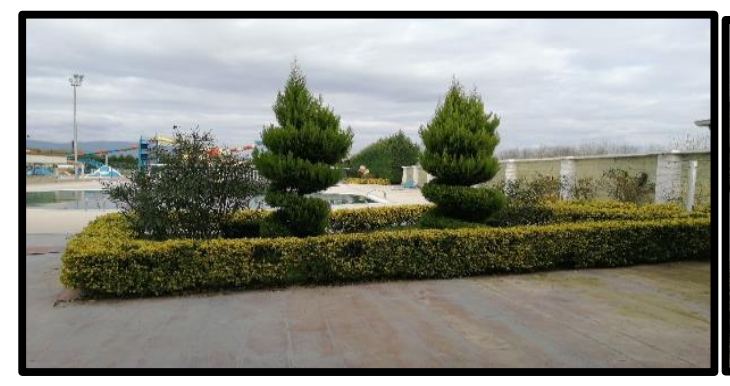

a)

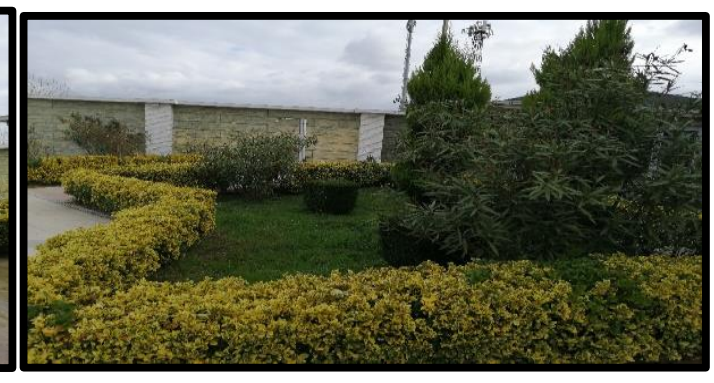

b)

Şekil 3. Düzce Su Parkı Bitkilendirme (a-b) [23].

Şekil 3'de görüldüğü üzere çeşitlilik açısından çok fazla zenginlik göstermeyen alan içerisinde en çok dikkat çelen bitkiler havuz alanları kenarlarından bulunan altuni taflan (Euonymus Japonicus "Aurea"), alev çalısı (Photinia Red Robin), limoni servi (Cupressus macrocorpa goldcrest), Leyland selvi (Cupressus leylandii), gelintacı (Weigela florida), parlak yapraklı kartopu (Viburnum Lucidum) ağırlıklı olarak kullanılmıştır.

13-Yerleşim Alanı $\left(\mathbf{m}^{2}\right)$ : Arazi büyüklüğü seçimi; bu konuda kesin değerler sunmak pek mümkün olmasa da $15.000 \mathrm{~m}^{2}$ ve üzeri yerleşim alana büyük ölçekli su parkı, $15.000-5.000 \mathrm{~m}^{2}$ yerleşim alanına sahipse orta ölçekli su parkı ve $5.000 \mathrm{~m}^{2}$ 'den az yerleşim alanına sahipse küçük ölçekli su parkı olarak değerlendirilmiştir. Düzce Su Parkı değerlendirme kriterinden 2 puan alarak orta ölçekli su parkı olarak değerlendirilmiştir.

14: Çocuk Animasyon Çeşitleri: Düzce Su Parkı toplamda 10 adet çocuk animasyonu bulunmaktadır. Yılan kaydırak, fil kaydırak, mini fil kaydırak, tavşan kaydırak, yunus fiskiye, mantar (200 mm), mini gökkuşağı, ahtapot kaydırak ve mini kurbağa bulunmaktadır. Düzce Su Parkı değerlendirme kriterinden toplam 2 puan almıştır. Şekil 4.'de gösterilmiştir. 


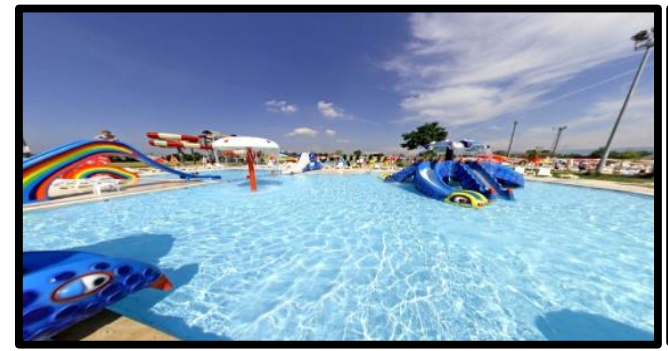

a)

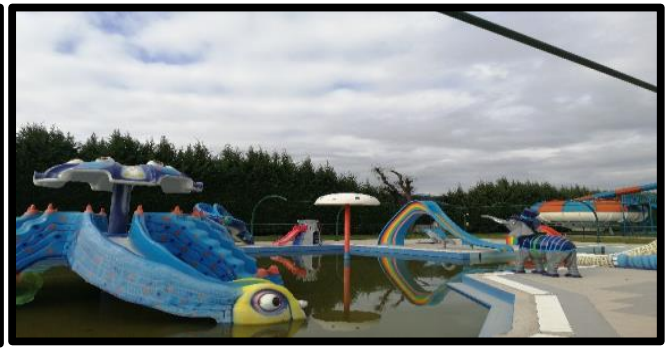

b)

Şekil 4. Düzce Su Parkı Çocuk Animasyonları(a-b) [23].

15- Kaydırak Seçimi: Alanda toplamda 7 kaydırak bulunmaktadır.

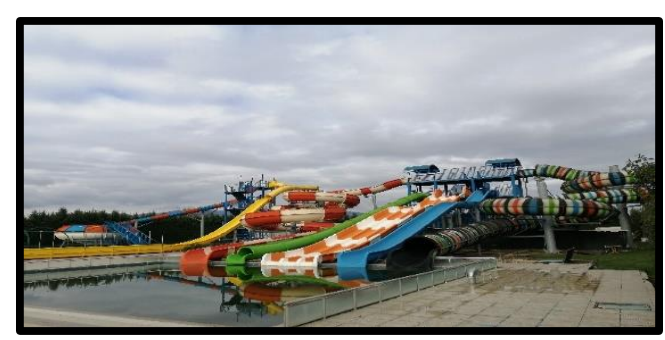

a)

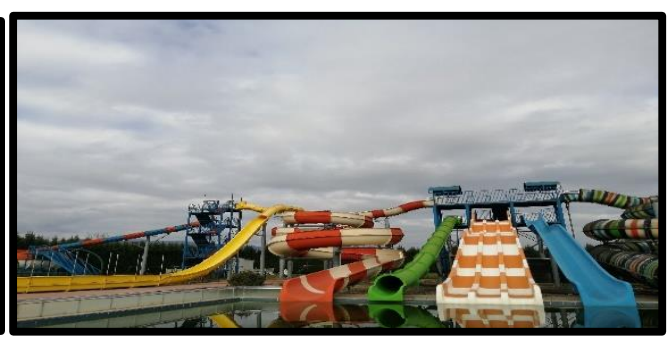

b)

Şekil 5. Düzce Su Parkı Kaydırak Görünüşü (a-b) [16].

Şekil 5'de görüldüğü gibi, Rafting slide, tunnel freefall, multislide, kamikaze, black hole, space boat, body slide kaydırakları mevcuttur. 2 puan almıştır.

16- Su Öğesi Kullanımı: Düzce Su Parkında toplam 4 havuz bulunmaktadır. Bunlar;

*Yüzme Havuzu: $550 \mathrm{~m}^{2}$ *Çocuk Havuzu: $300 \mathrm{~m}^{2}$ *Düşme Havuzu -1: $180 \mathrm{~m}^{2}$ *Düşme Havuzu -2: 25 $\mathrm{m}^{2}$ bulunmaktadır. 2 puan almıştır.

17- Sezon Dışı Kullanımı: Alan içerinde sezon dışı aktivitelerin eklendiği dikkat çekmektedir. Park yönetimi aktivitelerin işleyişini yakından incelemekte ve işlerliğini kaybeden aktiviteleri tespit edip yerine yeni aktiviteler planlanmaktadır. Sezon dışı hizmet vermek amacı ile giriş binasının üst kısmı balık restoranı yapılmış, fakat işlemediği için kapatılıp organizasyon ve toplantı alanı olarak revize edildiği gözlemlenmiştir. Ayrıca alanda kapalı ve açık düğün alanı mevcuttur Düzce Su Parkı değerlendirme kriterlerine göre 3 puan almıştır.

18- Bilgi İletişim Levhaları: Bilgi iletişim levhaları ise alan içerisinde bulunmakta olup bütün kaydırakların giriş kısımlarında kaydırakla ilgili bilgiler verilmiştir. Bu levhalar yeterli sayıda olup, biçim ve büyüklük açısından da uygun olduğu görülmüştür. Bilgi iletişim levhaları Alan değerlendirme kriterine göre 3 puan almıştır. Şekil 6.'da gösterilmiştir. 


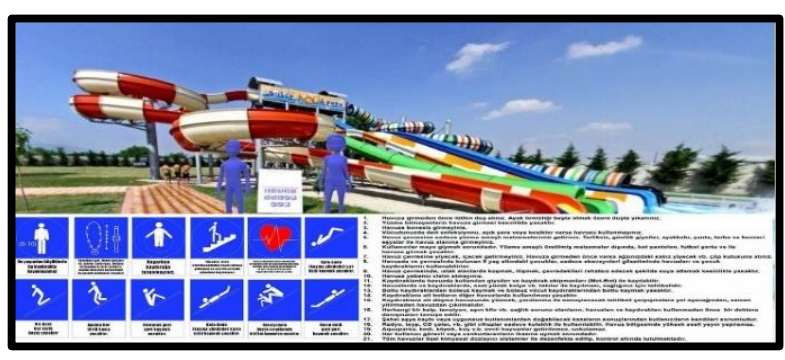

a)

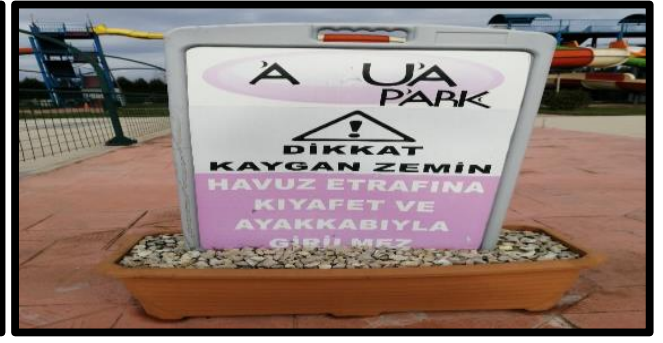

b)

Şekil 6. Düzce Su Parkı Bilgi İletişim Levha Görünümü(a-b) [23].

19- Donatı Elemanları: Belirlenen kriterlerden 3 puan almıştır. Şekil 7.'de gösterildiği gibi alan içerisinde beyaz renkli şezlonglar bulunmakta ve havuz çevresine yerleştirilmiştir. Havuz etrafinda ağaçlandırma bulunmaması nedeniyle alan güneşe çok maruz kalmakta olup oturma elemanlarının şemsiyeler vasıtasıyla güneşten korunduğu tespit edilmiştir. Alan içerisinde çöp kovalarının yeterli olduğu tespit edilmiştir. Çöp kovaları mavi ve gri renklidir. Oturma alanlarının bulunduğu bölgelerde çöp kovasına rastlanmaktadır. Alan içerisinde gece kullanımı tespit edilmiş olup yeterli miktarda aydınlatma elemanı görülmüştür. Aydınlatma elemanları yeme içme bölümlerinde ve havuz çevresinde yeterli miktarda bulunmaktadır. Özellikle havuz başı düğün organizasyonları yapıldığı için alan yeteri miktarda aydınlatma elemanı kullanılmıştır.

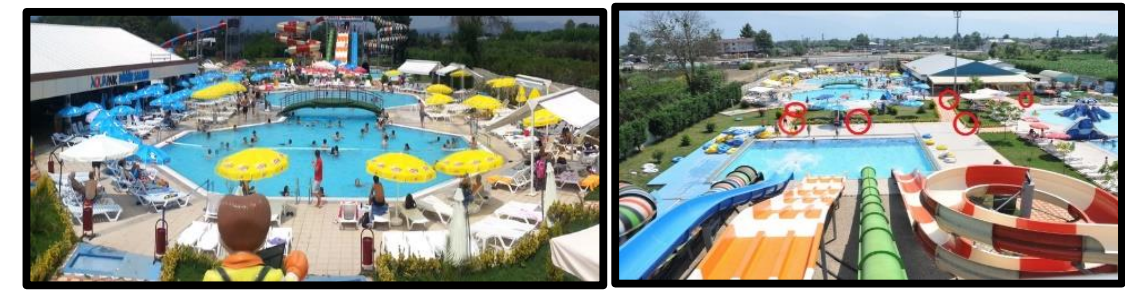

a)

b)

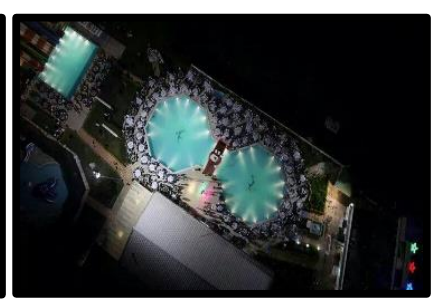

c)

Şekil 7. Alanda Şezlong, Çöp Kovası ve Aydınlatma Elemanları Görünümü (a-b-c) [16].

20- Hedef Kitle: Düzce Su Parkının hedef kitlesi; bulunduğu il, çevre iller ve ilçelerdir. Bu bakımdan Düzce Su Parkı değerlendirme kriterinden 2 puan almıştır.

Tablo 4. Düzce Su Parkı'nın Değerlendirme Tablosu.

\section{PUANLAMA}

\section{DEĞERLENDİRME KRİTERI}

\begin{tabular}{lllll} 
& & $\mathbf{1}$ & $\mathbf{2}$ & $\mathbf{3}$ \\
\hline $\mathbf{1}$ & Ulaşım-Konum & & 3 \\
\hline $\mathbf{2}$ & Şehir Nüfusu & & 2 \\
\hline $\mathbf{3}$ & İklim & 1 & \\
\hline $\mathbf{4}$ & Konaklama & & 2 \\
\hline $\mathbf{5}$ & Otopark Yeterliliği & 1 & 2 \\
\hline $\mathbf{6}$ & Güvenlik & & 2 \\
\hline $\mathbf{7}$ & Sağlık Birimi & 2 \\
\hline $\mathbf{8}$ & Yeme-İçme Birimleri & \\
\hline $\mathbf{9}$ & Soyunma Birimleri-Duş-Wc & & \\
\hline
\end{tabular}




\begin{tabular}{llcc}
\hline $\mathbf{1 0}$ & Kente Uzaklık & 1 & 3 \\
\hline $\mathbf{1 1}$ & Engelliler İçin Düzenlemeler & & 3 \\
\hline $\mathbf{1 2}$ & Bitkilendirme & 2 & 3 \\
\hline $\mathbf{1 3}$ & Yerleşim Alanı m & & \\
\hline $\mathbf{1 4}$ & Çocuk Animasyon Çeşitleri $^{2}$ & 2 & \\
\hline $\mathbf{1 5}$ & Kaydırak Seçimi & 2 & 3 \\
\hline $\mathbf{1 6}$ & Su Öğesi Kullanımı & & 3 \\
\hline $\mathbf{1 7}$ & Sezon Dişı Kullanımı & & 3 \\
\hline $\mathbf{1 8}$ & Bilgi-İletişim Levhaları & & \\
\hline $\mathbf{1 9}$ & Donatı Elemanları & 2 & 21 \\
\hline $\mathbf{2 0}$ & Hedef Kitle & 20 & \\
\hline Toplam & 3 & & \\
\hline Genel Toplam: $\mathbf{4 4}$ & & & \\
\hline
\end{tabular}

Tablo 4'de belirlenen kriterler doğrultusunda Düzce Su Parkı, gözlem formu ile oluşturulan dereceli puanlama, tez kapsamında belirlenen tasarım elemanları ve kriterleri doğrultusunda değerlendirme tablolarında puanlama yapılmıştır.

Çalışma kapsamında incelenen Düzce Su Parkı örneği 44 puan alarak temsil derecesi orta olarak belirlenmiştir.

Su parklarının incelenmesi konusunda son yıllarda çeşitli çalışmalar yapılmıştır.

Malkoç, E., (2002), “Aquaparkların (Su parklarının) Planlama ve Tasarım İlkeleri Üzerine Bir Araştırma", isimli çalışma, su parkları hakkında hemen hemen birçok bilgiye ulaşılabilen yüksek lisans çalışmasında, su parklarının planlanması ve parklarda kullanılan araçlar hakkında geniş bir bilgi verilmiş olup Türkiye'de bulunan su parklarında tespit çalışmaları yapmıştır. Su parkların mevcut planları incelenmiş, iyi ve eksik yönleri ortaya konulmuş olup dünyada bulunan bazı parklardan örneklere yer verilmiştir. Çalışmada su parklarının fiziksel durumunu irdelemiş olup, araştırma alanlarının tasarım açısından uygunluğu, fonksiyonelliği ve zenginliği gibi olguları değerlendirmiştir. Türkiye'nin farklı bölgelerinde bulunan parklar irdelenmiş ve karşılaştırılmıştır. Türkiye'deki 14 adet su parkı araştırma alanı olarak değerlendirilmiş, alan çalışmaları sırasında seçilen su parklarının konumsal ve fiziksel yapıları analiz edilmiş, mekânsal içeriği sorgulanmış gerek su parkı işletmecileri gerekse ziyaretçilerden alınan bilgiler 1şı̆̆ında örnekler yakından incelenmiş yer, seçim kriterleri, mekân gereksinimleri ve tasarım kriterleri ortaya konulmuştur.

Nacak, H., (2000), “Aquapark'ların Yer Seçim İhtiyaçları ve Tasarım Kriterlerinin İncelenmesi”, isimli yüksek lisans tezinin giriş bölümünde boş zaman, oyun, rekreasyon kavramları tek tek ele alınmış bu kavramların birbirleri ile olan ilişkileri ortaya konmaya çalışılmıştır. Aynı bölümde su parkı, konulu parklar ve eğlence parklarına da değinilmiştir. Boş zaman kavramının tarihsel gelişme süreci anlatılmış ve yurt dişındaki boş zaman değerlendirmeye yönelik sistem ve organizasyonlardan detaylı olarak bahsedilmiştir. Tezde yurtdışından ve Türkiye'den çeşitli su parkı örneklerine yer verilmiştir.

Akgül, H., (2006), “Aquapark'ların Tasarım ve Planlama İlkeleri ve Ülkemizdeki Örnek Aquaparkların Değerlendirilmesi”, isimli çalışma, su parklarının dinamik yapısının hangi şekilde işlediği ve tasarım anlamında neler yapılabileceği gibi konularda sonuçlar çıkarılmışır. Su parkları tasarım ve planlanmasında dikkat edilecek unsurlar hususunda tespitler yapılmış ve öneriler getirilmiştir. Türkiye'nin farklı bölgelerinde bulunan parklar irdelenmiş ve karşılaştırılmıştır.

$\mathrm{Bu}$ örneklerde de görüldüğü gibi su parkları hakkında yapılan çalışmalar daha çok su parklarının genel özellikleri ve yurt içi-yurt dışı bazı su parklarının planlama ve tasarım kriterleri değerlendirilmiştir. Su parkının detaylı bir puanlamaya yer verilmediği görülmektedir. 
Bu çalışmayı, diğer örneklerden ayıran en önemli özellik, Düzce ilinde bulunan Düzce Su Parkı'nın genel özellikleriyle anlatmakla kalmayıp su parkı hakkında, su parkının tasarım ve planlama ilkelerine uygunluk açısından detaylı bir puanlama çalışması yapılması, parklarda görülen eksikliklerin belirtilmesi ve bu eksikliklerin giderilmesi konusunda öneriler sunmasıdır. Araştırma alanında gerçekleştirilen görsel analiz çalışmalarında alan kullanımı (yapılış amacına uygunluk, yer seçimi, bakım-yönetim), donatı elemanları (döşeme kaplaması, bitki kapları, aydınlatma elemanları, plastik elemanlar, bilgi iletişim ve reklam panoları, oturma birimleri, çöp kutuları), erişe bilirlik (otopark olanağı, alana ulaşım olanakları, sosyal-kültürel mekanlarla alanın ilişkisi, alanın çevreden algılanmassı) ve tasarım ögeleri (renk, biçim, ölçü) bakımından değerlendirilmiştir. Ayrıca araştırma alanında yetiştirilen bitki örtüsünü, türleri ve yoğunlukları tezde de belirttiğim üzere ağırlıklı olarak kullanılan bazı türler tespit edilmiştir.

\section{IV.SONUC}

Yapılan inceleme ve yöntemde de belirtildiği üzere daha önce yapılmış çalışmaları materyal olarak kullanmış ve yeni gözlemlerle toplanan bu bilgiler değerlendirilip planlama ve tasarım kriterleri açısından optimum özelliklere sahip bir su parkının hangi özellikleri ne kadar içermesi gerektiği konusunda daha güncel, geçerli ve gerçekçi sonuçlara varılmaya çalışılmıştır. Belirlenen değerlendirme kriterleri önem derecelerine göre puanlandırılarak su parkı değerlendirme matrisi oluşturulmuştur. Su parkının bulunduğu konumun, demografik yapısı, ulaşılabilirliği, nüfusu gibi kriterler baz alınarak temsil derecelerine göre puanlama yapılmıştır. Bu noktada su parklarının dinamik yapısı ve bu hareketliliğe karşı nasıl önlemler alınacağına bir cevap aranmıştır.

Düzce Su Parkı, yerinde yapılan gözlemler sonucunda, parkın kuruluşundan itibaren geçirmiş olduğu değişim tespit edilip park genelindeki değişiklikler ortaya konmuştur. Bu değişimler;

* İlave kaydırak

*Açık-kapalı düğün alanları

*Restoran ve organizasyon alanları eklenmiştir.

Düzce Su Park1 için önemli 20 değerlendirme kriteri belirlenmiş olup, bu kriterler doğrultusunda Düzce'de bulunan Düzce Su Parkı yerinde incelenmiştir. Düzce Su Park1 44 puan alarak orta temsil grubuna girmiştir.

1 puan alan 3 kriter;

- Konaklama

Su parkının kendine özgü konaklama birimleri bulunmamaktadır. Şehir dışından gelen su parkı müşterileri için, su parkı bünyesinde en az bir konaklama biriminin bulundurmalı.

- Sağlık Birimi

Alan içerisinde sağlık birimlerini olmaması büyük bir eksiklik olarak göze çarpmaktadır. Su parkı bünyesinde kullanıcı sayısına uygun büyüklükte ve donanımda bir revir alanı planlanmalı, bu revirde su parkının açık olduğu saatler boyunca görevli sağlık personeli bulunmalıdır.

- Engelliler İçin Düzenlemeler

Su parkı alanlarında engelliler için düzenlemeler bulunmamaktadır. Engelliler için düzenlemeler yapılmalı alan içerisinde özel aktivite alanları ayrılmalıdır.

$\checkmark$ Su parkının bulunduğu alanda yollar, rampa ve merdivenler engellilerin rahatça kullanımına uygun hale getirilmeli,

$\checkmark$ Engelli kullanımına uygun donatı elemanları ve otopark olmalı (şezlong, çöp kutusu vs.) 
$\checkmark$ Havuzlara yakın bedensel engelli kullanımına uygun wc, soyunma kabinleri ve duşun bulunmalı (en az 1 adet)

$\checkmark$ Havuzların tasarımı (derinlik ve uzunluk kademeleri) engelliler de düşünülerek planlanmalı

$\checkmark$ Havuzların en az birinde manuel havuz transfer sistemi bulunması (55 cm genişliğinde, 30-45 $\mathrm{cm}$ derinliğinde ve $17 \mathrm{~cm}$ yükseklikte suyun altına inen transfer basamakl1; havuz kenarında 40$45 \mathrm{~cm}$ yüksekliğinde transfer duvarı olan ve önünde 150x150 cm'lik tekerlekli sandalye park1 için alanı olan) [24] ya da Portatif Havuz Lifti Bluone engelli ve hareket kısıtlılığı yaşayanların havuza transferi için dizayn edilmiş hızlı, rahat ve güvenli bir erişim cihazını bulundurmalı [25],

$\checkmark$ Su parkı tasarlanırken engellilerin de alandan yararlanabileceği düşünülmeli tasarım bu yönde şekillenmelidir.

2 puan alan 10 kriter;

- Şehir Nüfusu

Su parkının olduğu, bölge de halkın sosyalleşmesine, eğlence ihtiyaçlarının karşılanmasına çok pozitif etkilerinin olmasının yanı sıra, dışarıdan yoğun gelecek ziyaretçiler üzerinden de ticari hayatını zenginleştirip hem de ekonomik kapasitesini artırmaya yardımcı olacaktır. Su parkı iyi tasarlanıp planlanırsa günlük kullanıcı kapasitesini arttırabilir.

- İklim

Su parkı tasarımında iklim çok önemlidir. Düzce Su Parkı, hava sıcaklı̆̆ına bağlı olarak Haziran - Eylül ayları arasında 3 aylık bir sezonda hizmet vermektedir. Diğer bölgedeki su parklarına göre daha hizmet vermektedir. Bunun için farklı aktiviteler yapmalı sezon dışında kullanımlara ya da su parkının belli bir kısmını kapalı su parkı olarak tasarım ve planlama yapılmalıdır.

- Otopark Yeterliliği

Park alanı girişinde, $3.000 \mathrm{~m}^{2}$ açık otopark1 mevcut olmakla birlikte otopark alanı yeterli şekilde bitkilendirilmemiştir. Alanda park eden araçlar güneşe maruz kalmaması için bitkilendirme yapılmalıdır. Yıllar içerisinde alan ile ilgili yenileme çalışmalarının yapılması kişi kapasitesini arttırmıştır. $\mathrm{Bu}$ nedenle planlama esnasında planlanan otopark büyüklüğü yıllar içerisinde yetersiz kalmıştır. Toplam $15.000 \mathrm{~m}^{2}$ alan için $\left(15.000 / 30 \mathrm{~m}^{2}\right) 500$ araçlık otopark alanı olması gerekiyor. 3.000 otoparkı bulunan Düzce su parkı 150 araçlık otopark yeri mevcuttur. Standartların altındadır. Bunun için otopark alanı genişletilmelidir.

- Güvenlik

Kullanıcıların güvenliği de çok önemlidir, bu konuda uzman kişiler ile çalışılmalı, güvenlik önlemleri yönünden standartlar geliştirilmelidir. Her havuz ve kaydırak için ayrı ayrı, en az 2 dilde hazırlanmış, aktivitenin nasıl kullanılacağının yazılı ve görsel olarak yönlendirici tabelalar bulundurulmalıdır. Su parklarında çalışan elemanların eğitilmesi için gerekli çalışmalar yapılmalı, özellikle tehlike anında ilk müdahale konusunda eğitimleri sağlanmalıdır.

Her havuzda mutlaka bir can kurtaranın (gerekli belgeye sahip) hazır bulunup, dikkatle kullanıc1ları izlemesi gerekmektedir. Bu konuda özellikle çocuk havuzu önem taşımaktadır.

Yine aynı şekilde her kaydırak için bir operatör bulunup, (gerekli eğitimi almış) o kaydırağa uygun kullanım tipini, kullanıcıya tabela yardımı ile anlatıp, buna göre kullanıldığından emin olunması gerekmektedir. Kaydırakların periyodik bakımları sürekli yapılmalı ve kaydırak parçalarının birleşme noktalarında oluşan ve kullanıcıya zarar veren pürüzler yok edilmelidir.

- Yeme-İçme Birimleri

Kafe ve restoranlar max. kişi kapasitesine göre hesaplanmalı, yeterli sayıda ve hizmet vereceği gruba (yiyecek -içecek vb.) göre planlanmalıdır. Düzce Su Parkında $1.000 \mathrm{~m}^{2}$ alana kurulmuş fastfood alanı bulunmakta, alana ulaşım her noktada sağlanabilmektedir. Fastfood alanı kapalı alanda mevcut. Açık 
alanda mevcut herhangi kafe, restoran, satış birimi bulunmamaktadır. Açık alanlar alternatif olabilecek duruma getirilmeli, özgün ve orijinal tasarımlar hedeflenmeli birbirlerine göre ayırt edici özelliğe sahip olmaları sağlanmalıdır.

- Soyunma Birimleri-Duş-Wc

Park alanında tek giriş olup kadın ve erkek olarak ayrılmıştır. Duş açık alanda 2 adet kapalı alanda ise kadın ve erkek olarak 2'şer adet, wc soyunma odalarında 2'şer adet mescitte de 2'şer adet, soyunma odaları 4'er adet olup kadın soyunma dolab1 150 adet, erkek soyunma dolab1 ise 270 adet olarak gözlemlenmiştir. Günlük 1.100 kişi kapasiteli su parkı için yeterli sayıda duş, wc ve soyunma dolabı olmadığı görülmüştür. Kişi kapasitesine göre sayılar arttırılmalıdır. Giriş binası max. kişi kapasitesine göre hesaplanmalı ve buna göre wc, duş ve dolap adetleri belirlenmelidir.

- Çocuk Animasyon Çeşitleri

Değerlendirme kriterine göre 2 puan alan Düzce su parkı küçük çocuk animasyonu bakımından yeterli sayıda mevcuttur. Fakat aquatowers gruplarından herhangi bir oyun grubunun eklenmesi çocuklara yönelik aktiviteyi arttırabilir.

- Kaydirak Seçimi

$\checkmark$ Su parklarının içerisinde planlanan aktiviteler alanın büyüklüğü ve ekonomik duruma göre planlanmal1.

$\checkmark$ Düzce Su Parkında rafting slide, tunnel freefall, multislide, kamikaze, black hole, space boat ve bosy slide yetişkin kaydırağı bulunmaktadır. Kaydırak ve havuz sayısı ne kadar fazla ise su park1 daha zengin bir hal almaktadır.

$\checkmark$ Yıılar içerisinde araştırma alanında en çok görülen değişiklik ekstrem kaydıraklar grubunda yer alan body slide ve space boat kaydıraklarının alan içerisine eklenmesidir. Bu değişikliklerin müşteri potansiyelini etkilediği görülmüş̧ür.

$\checkmark$ Su parkı kullanıcılarının fikirleri doğrultusunda gelişme stratejileri belirlenmeli bu yönde çalışmalar yapılıp sektörel hayata geçirilmelidir.

$\checkmark \mathrm{Su}$ parkı alanlarının yenilenmesi sağlanmalı, farklı kaydırak türleri ve aktiviteler uygulanmalıdır. Sektörel gelişim mutlaka takip edilmeli kullanıcıların istedikleri ve alan için uygun kaydırak ve farklı aktivitelere yer verilmelidir.

- Su Öğesi Kullanımı

Havuzlar kullanıcının işini kolaylaştıracak şekilde planlanmalıdır. Su parkı alanlarının tasarımları bu konuda profesyonel kişiler tarafından yapılmalıdır. En az bir yüzme, çocuk ve düşme havuzu olarak gerekli büyüklüklerde tasarlanmalıdır. Alan ve bütçeye bağlı olarak bazı atraksiyon havuzları da ilave edilebilir. Bunlar dalga havuzu, tembel nehir, vahşi nehir, sörf havuzu, jakuzi olabilir. Havuz büyüklükleri ve havuz sayıları alana bağlı olarak verilmektedir.

- Hedef Kitle

$\checkmark \mathrm{Su}$ parklarının başarısı, çevresel, sosyal ve ekonomik etkileri gibi tek bir araştırmada incelenemeyecek kadar geniş çaplı konuları kapsamaktadır. Bununla birlikte, su parkının başarısında, hedef kitle önemli bir kriterdir. Yapılan değerlendirme kriteri sonucunda su parkının ziyaretçi sayısında en büyük etkenin, su parkının bulunduğu bölgenin demografik yapısı ulaşılabilirliği ve sezon dışı kullanımı olduğu görülmüştür.

$\checkmark$ Su parkının hedef kitlesini arttırmak için aktiviteler ve sezon dışı kullanımları arttırılmalı.

$\checkmark \mathrm{Su}$ parkında yazılı ya da görsel tanıtıma önem verilmeli bu konuda yapılan çalışmalar desteklenmelidir.

$\checkmark$ Hedef kitleyi arttırabilmek için işletmelerin olaya ticari olarak değil de topluma hizmet mantalitesi ile yaklaşmaları sağlanmalıdır.

3 puan alan 7 kriter;

- Ulaşım-Konum 
- Kente Uzakl1k

- Bitkilendirme

- Yerleşim Alanı $\mathrm{m}^{2}$

- Sezon Dışı Kullanımı

- Bilgi-İletişim Levhaları

- Donatı Elemanları

Düzce Su Parkı bu kriterlerden tam puan almıştır.

Su parkı alanlarında bulunan bitki örtüsünün aynen korunmaya çalışıldığ1 gözlenmiş olup, bu konuda peyzaj mimarları ile yapılan çalışmalarda bitkilerin havuz kenarlarından daha uzaklarda planlandığı gözlenmiştir. Havuz kenarlarında daha çok çalı türü bitkilerin planlandığı, yaprak döken ağaçların bu bölgelerde hiç yer verilmediği gözlemlenmiştir. Bu nedenle havuz kenarlarında bulunan açık alanlarda gölge ihtiyacı şemsiyeler ile sağlanmıştır.

Kentlerde yeşil alan ve parkların giderek azalması; bunların yerine ekonomik getirileri nedeniyle alışveriş merkezlerinin, kapalı spor salonlarının ve eğlence merkezlerinin yaygınlaşması, açık alanda rekreasyon ve boş zaman değerlendirme imkanlarının azalmasına neden olmuştur. Günümüzde su parkları, her yaşa hitap eden etkinlikler içermesi, teknolojiyle açık alanda rekreasyon imkanını bir araya getirmesi ve ekonomik getirileri nedeniyle cazip aktif rekreasyon alanları haline gelmiştir.

Yapılan bu çalışmanın önemini şu şekilde özetlemek gerekirse; su parklarının planlanmasında uyulması gereken birçok standardın oluşturulması ve bu tesislerin daha kullanışlı oluşturulmasında ışık olacaktır. $\mathrm{Bu}$ araştırma sonucunda elde edilen bilgiler, gelecekte yapılacak olan su parklarına katkı sağlayacak, aynı zamanda tüm çalışmalar için altlık ve yol gösterici bir kaynak olacaktır.

\section{KAYNAKLAR}

[1] B. Karaca, 'Başarılı Bir Su Parkı İçin Olması Gereken Planlama ve Tasarım Kriterleri' Yüksek lisans Tezi, Peyzaj Mimarlığı Anabilim Dalı, İstanbul Teknik Üniversitesi, İstanbul, Türkiye, 2018.

[2] A. Zaloğlu, 'Ankara Kent Parklarında Suyun Gösteri Elemanı Olarak İrdelenmesi’ Yüksek Lisans Tezi, Peyzaj Mimarlığı Anabilim Dalı, Ankara üniversitesi, Ankara, Türkiye, 2006.

[3] T. O'Brien, The Wave Maker: The Story of Theme Park Pioneer George Millay and the Creation of SeaWorld, Magic Mountain and Wet'n Wild., Ord ed., vol. 352, New Haven, USA: John Ripley Entertainment Inc, 2004, pp. 36-120.

[4] Anonim. (2020, 8 Mart). Park World Online [Çevrimiçi]. Erişim: https://www.parkworldonline.com/wet-n-wild-orlando-the-waterpark-that-made-waves-in-the-industry.

[5] H. Akgül, ‘Aqua parkların Tasarım ve Planlama İlkeleri ve Ülkemizdeki Örnek Aqua parkların Değerlendirilmesi’ Yüksek lisans Tezi, Peyzaj Mimarlığı Anabilim Dalı, Selçuk Üniversitesi, Konya, Türkiye, 2006.

[6] H. Nacak, 'Su Parkların Yer Seçim İhtiyaçları ve Tasarım Kriterlerinin İncelenmesi' Yüksek Lisans Tezi, Şehir ve Bölge Planlama Ana Bilim Dalı, İzmir Yüksek Teknoloji Enstitüsü Üniversitesi, İzmir, Türkiye, 2000. 
[7] E. Malkoç, 'Aqua parkların (Su Parklarının) Planlama ve Tasarım İlkeleri Üzerine Bir Araştırma' Yüksek Lisans Tezi, Peyzaj Mimarlı̆ğ Anabilim Dalı, Ege Üniversitesi, İzmir, Türkiye, 2002.

[8] E. Dalkılıç, 'Eğlence Parklarının Tarihsel Gelişimi ve Planlama' Yüksek Lisans Tezi, Peyzaj Mimarlığı Anabilim Dalı, Ankara Üniversitesi, Ankara, Türkiye, 2007.

[9] A. B. Oruçkaptan, 'Su Parkı Planlama Kriterinin Saptanması ve Ankara Susuz Gölet'i Örneğinde Değerlendirilmesi Üzerine Bir Araştırma' Doktora Tezi, Peyzaj Mimarlığı Anabilim Dalı, Ankara Üniversitesi, Ankara, Türkiye, 2002.

[10] A. A. W. P. Wylson. Theme Parks, Leisure Centers, Zoos and Aquaria., 2rd ed., vol. 183, Los Angeles, California, USA: Longman Building Studies, 1994, pp. 78-96.

[11] T. H. Sawyer, Facility Planning and Design for Health, Physical Activity, Recreation, and Sport.,» 14rd ed., vol. 508, USA: Sagamore Publishing., 2013., pp. 120-280.

[12] S. Tankurt, 'Güney Ege ve Akdeniz Kıyılarında Yer Alan Tatil Köylerinin Tasarım Ve Planlama İlkelerinin Oluşturulmasına Yönelik Bir Araştırma' Yüksek Lisans Tezi, Peyzaj Mimarlığı Anabilim Dalı, Ege Üniversitesi, İzmir, Türkiye, 1999.

[13] R. Meyer. (2020, January 5). Theme Park Insider [Online]. Available: https://www.themeparkinsider.com/flume/201309/3655/.

[14] M. Y. E. Hatipoğlu, 'Firma Değerlemesinde İndirgenmiş Nakit Akımları Yöntemi: BIST Elektrik Endeksinde Bir Uygulama’ Eskişehir Osmangazi Üniversitesi İiBF Dergisi, c. 8, s.3, ss. 7-29, 2013.

[15] T. C. Düzce Valiliği. (20.05.2020) [Çevrimiçi]. Erişim: http://www.duzce.gov.tr/sehrimiz.

[16] U. Havuz, Ulusal Yüzme Havuzları Fotoğraf Arşivi., (15.02.2019), [Çevrimiçi]. Erişim: https://www.ulusalhavuz.com/tr

[17] Anonim (20.05.2020), Google Earth Harita. [Çevrimiçi]. Erişim: https://earth.google.com

[18] C. S. Yaylacı, 'Anaokul Bahçelerinde Dış Mekân Kullanım Olanaklarının Belirlenmesi, İstanbul Anadolu Yakasından Örnekler' Yüksek Lisans Tezi, Peyzaj Mimarlı̆ğ Anabilim dalı, Düzce Üniversitesi, Düzce, Türkiye, 2019.

[19] M. T. Güneri, 'Kentin Düğüm Noktaları Olan Meydanların Peyzaj Mimarlığı Açısından Değerlendirilmesi, Mersin İli Örneği’ Yüksek Lisans Tezi, Peyzaj Mimarlığı Anabilim dalı, Düzce Üniversitesi, Düzce, Türkiye, 2019.

[20] M. F. Tekinalp, 'Japon Bahçesi Tasarım Kriterleri Açısından Türkiye'deki Bazı Japon Bahçelerinin Değerlendirilmesi' Yüksek Lisans Tezi, Peyzaj Mimarlığı Anabilim dalı, Düzce Üniversitesi, Düzce, Türkiye, 2017.

[21] C. Hatipoğlu, Interviewee, Düzce Aquapark. [Röportaj]. 03072020.

[22] Anonim. (20.05.2020) [Çevrimiçi]. Available: https://duzce.ktb.gov.tr/TR-211369/iklimi-vebitki-ortusu.html. 
[23] R. Sönmez, Artist, Düzce Aquapark Fotoğrafları. [Art]. 2020.

[24] Anonim. (2020, 26 Mayıs). Tesisin Konumu Ve Yakın Çevresi B- Tesisin Engelsiz Turizm Politikası [Çevrimiçi]. Erişim: http://tourismforall.org.tr/Documents/Engelsiz-isletme-siniflandirmaFormu 05-04-2013.pdf.

[25] Anonim. (26.05.2020). Engelsiz Ürünler [Çevrimiçi]. Erişim: http://www.engelsizurunler.com.tr/ur_er_havuza_erisim.html. 